\title{
Intake and digestibility of concentrate and legume hay diets fed to foals
}

\section{Vinicius Pimentel Silva ${ }^{1}$, Adalgiza Souza Carneiro de Rezende ${ }^{1}$, Eloisa de Oliveira Simões Saliba $^{1}$, Maria Lindomárcia Leonardo da Costa ${ }^{1}$, Julia Timponi de Moura Lima $^{2}$, Renata Vitarele Gimenes Pereira ${ }^{2}$}

\footnotetext{
${ }^{1}$ Programa de Pós-graduação em Zootecnia/ Faculdade de Veterinária - Universidade Federal de Minas Gerais - UFMG.

${ }^{2}$ Curso de Medicina Veterinária - Universidade Federal de Minas Gerais.
}

ABSTRACT - This study was carried out to evaluate intake, nutrient digestibility and body weight gain of foals on diets of concentrate and legume hay. Treatments were: lucerne hay (Medicago sativa), Campo Grande stylo hay (20\% Stylosanthes macrocephala and $80 \%$ Stylosanthes capitata) and Mineirão stylo hay (Stylosanthes guianensis cv. Mineirão). Fifteen weaned foals at $160 \mathrm{Kg}$ body weight (BW) were used. The experiment was entirely randomized with three treatments and five replicates. Dry matter intake was estimated at $30 \mathrm{~g}$ of dry matter (DM)/kg BW and was comprised of $40 \%$ concentrate meal and $60 \%$ hay. Fecal production and nutrient digestibility were calculated by the LIPE ${ }^{\circledR}$ marker methodology. There was no difference between Lucerne hay and Campo Grande stylo hay intake, but intake of Mineirão stylo hay was lower than that of Lucerne hay. Body weight gain and nutrient digestibility coefficients were similar for foals fed different diets. Intake was similar for Campo Grande and Lucerne hay, and led to similar body weight gain in diets with concentrate. Mineirão stylo hay, at 137 days of growth, was not palatable for the foals.

Key Words: horse, lucerne, marker, roughage, stylo, tropical

\section{Introduction}

In Brazil, Cynodon spp. and Lucerne hay are the most common types of hay fed to horses (Lima et al., 2006). In this country, horse nutrition is based on a limited number of food types with few alternatives. Moreover, there is a general lack of awareness of alternative types of forage and appropriate dietary programs to deal with equine nutrition problems (Manzano et al., 1979).

Silva et al. (2009) evaluated the digestibility coefficients of several legumes for horses but did not identify the voluntary feed intake of these feed types. It was concluded that Mineirão stylo hay, peanut hay and Macrotyloma showed potential for use in horse diets, considering their high apparent digestibility.

Acceptance of roughage by herbivores can be evaluated by the voluntary dry matter (DM) intake. However, Van Soest (1994) noted that the biggest problem is determining why animals reject the feed. Because animals are incapable of directly communicating their preferences, it is difficult to distinguish if their rejection or acceptance is the result of palatability or physiological factors.

Innumerable forage options are available in tropical areas. While there are studies that evaluate their quality for horses, there is a need for studies that look at characteristics peculiar to horses (Domingues, 2009) and carefully evaluate voluntary feed intake of these forages under practical conditions (Dittrich et al., 2005; Silva et al., 2009).

It is expected that tropical forages have potential uses in the equine diet, and that new forages that are highly digestible, perennial, inexpensive and that increase the number of options available in feed regimens be proposed. Therefore, specific studies are needed to evaluate digestibility, nutritional value and voluntary intake to determine their correct usage in diet regimens.

The objective of this study was to evaluate dry matter intake, weight gain and nutrient digestibility coefficients of three different diets containing leguminous hay as forage for foals.

\section{Material and Methods}

The experiment was carried out on Santa Helena Farm Haras Catuni, located in Montes Claros, Minas Gerais (16 $41^{\circ}$ ' 161" south latitude, $43^{\circ} 31^{\prime} 210^{\prime \prime}$ east) at an altitude of 784 meters. The region has a dry season from March until September. Climatological records from the last 14 years on the farm indicate average annual precipitation of 1,100 mm.

The treatments were lucerne hay (Medicago sativa), Campo Grande stylo hay (physical mixture of $20 \%$ 
Stylosanthes macrocephala and 80\% Stylosanthes capitata) and Mineirão stylo hay (Stylosanthes guianensis cv. Mineirão).

Campo Grande stylo seeds were acquired commercially, while Stylosanthes guianensis cv. Mineirão was granted by Embrapa Cerrado (Agricultural Research Corporation of Brazil), 2001 harvest.

Campo Grande and Mineirão hays were produced at the Santa Helena Farm - Haras Catuni according to the haymaking process proposed by Haddad \& Castro (1998). Two and a half hectares were planted (1.5 ha Campo Grande and 1 ha Mineirão). Planting took place from December 10th to 12th, 2007 and seeds were sown in rows spaced $40 \mathrm{~cm}$ apart. Hay was harvested at 137 days of growth. The plants were cut by hand at a height of $20 \mathrm{~cm}$ above the soil as recommended by Skerman et al. (1991). To standardize the dehydration process, the hay was ground up and spread in a thin layer to dry in the sun. Lucerne hay was purchased commercially and was also ground.The experimental diets composed by concentrate and legume hay (Table 1) were calculated for a daily intake of $30 \mathrm{~g} \mathrm{DM} / \mathrm{kg}$ body weight (BW).

Fifteen Mangalarga Marchador foals, weaned at $165 \pm 9$ days, were used. The foals were all from two stallions but from different sires and were born between December 2007 and February 2008. The average body weight (BW) of the foals was $160 \pm 15 \mathrm{~kg}$. Foals were distributed into the treatments by being divided into groups of three. Each group was sired by the same stallion and as close as possible to the same age. Foals were then selected randomly into each treatment from each group of three. As soon as the foals reached 6 months of age, they were weaned, dewormed (Ivermectin plus Vit E) and held for 30 days in a paddock of Cynodon spp., receiving concentrate at 9:00 am and 5:00 pm each day until the beginning of the trial.

On the first day of the trial, foals were dewormed again and weighed to determine dry matter intake(DMI), calculated according to the NRC (2007). Daily intake was determined to be $30 \mathrm{~g} \mathrm{DM} / \mathrm{kg}$ body weight (BW), (40\% concentrate and $60 \%$ roughage), to meet the requirements for animals six months of age with an estimated mature body weight of $400 \mathrm{~kg}$.

The foals were kept in individual stalls and exercised daily at a walk, trot and gallop for 20 minutes. The facilities measured $3 \times 3$ meters, were open and had dirt floors, partitions and linear troughs. The stalls were cleaned every day in the morning and concentrate was provided twice daily at 9:00 am and 5:00 pm. Hay, water and mineral salt (Ca - 185 g; Na - 120 g; P - 60 g; K - 20g; Mg - 13.6 g; S - 12 g; Zn - 2200 mg; Fe - 2000 mg; Cu - 1200 mg; Mg - 970 mg; F - 600 mg; I - 125 mg: Co - 21 mg; Se - 10 mg) were provided ad libitum.

The design was entirely randomized with three treatments and five replicates. The following factors were assessed: length of time needed to adapt to the diet, weight gain, apparent digestibility and voluntary feed intake of hays, total diet and crude protein. The following model was used:

$\mathrm{Y}_{\mathrm{ij}}=\mathrm{m}+\mathrm{T}_{\mathrm{i}}+\mathrm{e}_{\mathrm{ij}}$

where $Y_{i j}=$ the value observed from variable on treatment $i$ ( $i=1,2,3)$ and repetition $j(j=1,2, \ldots 5)$, where $T_{i}=$ the effect of treatment $i, e_{i j}=$ the error associated with observation $Y_{i j}$, or the effect of the uncontrolled variables on the observation $Y_{i j}$

The length of the experiment was 125 days. Each group of three foals, as close as possible in age, was confined for 25 days to determine voluntary intake (the first 19 days) and digestibility (the last 6 days). During the phase to determine roughage intake, hay was offered ad libitum until wastage portion stabilized at $10 \%$. The uneaten portion was weighed each morning on a mechanical scale to determine stabilization and voluntary feed intake in $\mathrm{g} / \mathrm{kg} \mathrm{BW}$. During the digestibility trial, a diet containing $10 \%$ less than the average intake (based on the last five days of the intake determination phase) (Van Soest, 1994; Crozier, et al., 1997), was provided to avoid leftovers, so that the foals would consume everything that was fed to them. The final weight of the foals was determined after 25 days.

Table 1 - Average chemical composition of lucerne hay (Medicago sativa), Campo Grande stylo hay (physical mixture of 20\% Stylosanthes macrocephala and 80\% Stylosanthes capitata), Mineirão stylo hay (Stylosanthes guianensis cv. Mineirão) and concentrate $^{1}$

\begin{tabular}{|c|c|c|c|c|c|c|c|c|c|c|c|c|}
\hline \multirow[t]{2}{*}{ Feed } & $\mathrm{DM}$ & OM & $\mathrm{MM}$ & CP & $\mathrm{EE}$ & NDF & $\mathrm{ADF}$ & HEM & $\mathrm{Ca}$ & $\mathrm{P}$ & Mg & GE (Mcal/kg) \\
\hline & \multicolumn{12}{|c|}{$100 \% \mathrm{DM}$} \\
\hline Lucerne & 91.0 & 89.2 & 10.9 & 17.7 & 3.4 & 56.0 & 34.6 & 21.4 & 1.39 & 0.77 & 0.29 & 4.3 \\
\hline Mineirão & 89.5 & 91.1 & 8.9 & 11.1 & 3.9 & 67.6 & 46.6 & 21.0 & 1.53 & 0.27 & 0.24 & 4.4 \\
\hline Concentrate $^{1}$ & 89.4 & 92.8 & 7.2 & 10.9 & 4.6 & 22.7 & 3.5 & 19.2 & 1.72 & 0.76 & 0.22 & 4.2 \\
\hline
\end{tabular}

$185 \%$ ground corn, $10 \%$ soybean meal, $2.5 \%$ limestone, $1.5 \%$ dicalcium phosphate, $0.5 \%$ mineral salt, $0.5 \%$ soybean oil.

$\mathrm{DM}=$ dry matter; $\mathrm{OM}=$ organic matter; $\mathrm{MM}=$ mineral matter; $\mathrm{CP}=$ crude protein; $\mathrm{EE}=$ ether extract; NDF = neutral detergent fiber; $\mathrm{ADF}=$ acid detergent fiber; HEM = hemicellulose; GE = gross energy. 
Starting on the eighteenth day of the experiment, 500 mg LIPE ${ }^{\circledR}$ marker capsules (Saliba, 2005) were orally administered. This was done in order to estimate fecal production and to calculate digestibility. The marker capsules were administered daily at 9:00 am with the concentrate. Feces started to be collected two days after the start of indicator administration so that homogenization could occur throughout the entire digestive tract. After collection, administration continued for an additional four days (for a total of 6 days).

Feces sampling began on the third day and continued once per day for five days. The feces were collected at nine in the morning, directly from the floor and immediately after defecation. All the feces were collected, except the portion that had contact with the floor.

Hay, concentrate and feces samples were frozen and remained so until they were sent to the Laboratory of Animal Nutrition in the Department of Animal Science of the Faculty of Veterinary of UFMG, where they were ovendried, ground to $1 \mathrm{~mm}$ and analyzed according to the AOAC (1995) and Van Soest et al. (1995). Analyses of calcium (Ca) and magnesium (Mg) were determined by atomic absorption spectrophotometry (GBC Avanta, version 2.02) at the Laboratory of Chemical Analyses of the Faculty of Chemical Engineering of UFMG.

LIPE ${ }^{\circledR}$ levels were determined by infrared spectroscopy with Fourier transformations using a FTIV- LAB with HATR (Búhler ${ }^{\circledR}$ ). Five-gram samples of dry matter, exposed to nondestructive infrared, were used. LIPE ${ }^{\circledR}$ content was determined and fecal production was estimated from the feces. Fecal production was calculated using the external marker LIPE ${ }^{\circledR}$, according to the method described by Saliba (2005):

$\mathrm{FP}(\mathrm{kg})=\frac{\text { Supplied } \mathrm{LIPE}^{\circledR}(\mathrm{g}) \times 100}{\left(\mathrm{Ai} / \mathrm{DM}_{\text {total }}\right)}$

where: $\mathrm{FP}=$ fecal production; $\mathrm{Ai}=$ logarithmic ratio of the absorption band intensities of wavelengths at $1,050 \mathrm{~cm}^{-1} /$ $1,650 \mathrm{~cm}^{-1}$; DM total $=$ total fecal dry matter.

Ai was calculated using the following formula:

$\mathrm{Ai}=\mathrm{A} 1050 / \mathrm{A} 1650$

where: $\mathrm{A}={ }_{\log } \frac{\mathrm{I} 0}{\mathrm{I}}$

where I0 > intensity and I < intensity.

The digestibility coefficient (DC) of the diet was obtained using the formula:

DC $(\%)=($ Nutrient intake $)-($ Nutrients excreted in feces $) \times 100$ (Nutrient intake)

Weight gain, digestibility, voluntary intake of hay, total diet and crude protein were tested by analysis of variance. Means were compared by the Student-Newman
Keuls test at 5\% probability using the SAEG package (Statistical and Genetic Analysis System, version 8.0). All procedures used in this trial were approved by the Committee on Animal Ethics and Experimentation (CETEA/UFMG/124/08).

\section{Results and Discussion}

During the voluntary intake evaluation period, DM intake varied between hay types relative to the total amount supplied (Figures 1, 2 and 3). After the fifteenth day, average hay intake stabilized. Lucerne hay intake varied more during the first 14 days, but $8.8 \%$ less than average during the last five days, whereas Campo Grande and Mineirão stylo hay intake deviated more in the last five days (17.3 and $14.1 \%$, respectively).

One animal on the Mineirão stylo hay diet died at the end of the intake assessment. Necropsy showed fecal impaction at the end of the colon. Thus, one repetition was lost in this treatment.

There was no difference ( $\mathrm{P}>0.05)$ between Lucerne hay and Campo Grande intake (Table 2). Campo Grande intake did not differ from that of Mineirão ( $\mathrm{P}>0.05$ ); however, Mineirão intake was lower than that of Lucerne hay $(\mathrm{P}<0.05)$. Thus, it could be inferred that this lower intake was probably the result of palatability factors. However, because animals are incapable of directly communicating their preferences, it is difficult to distinguish whether rejection is the result of palatability or physiological factors (Van Soest, 1994).

Numerous studies have been carried out on Lucerne hay and in some cases, in comparison with other roughage types. In a study by LaCasha et al. (1999), yearling Quarter

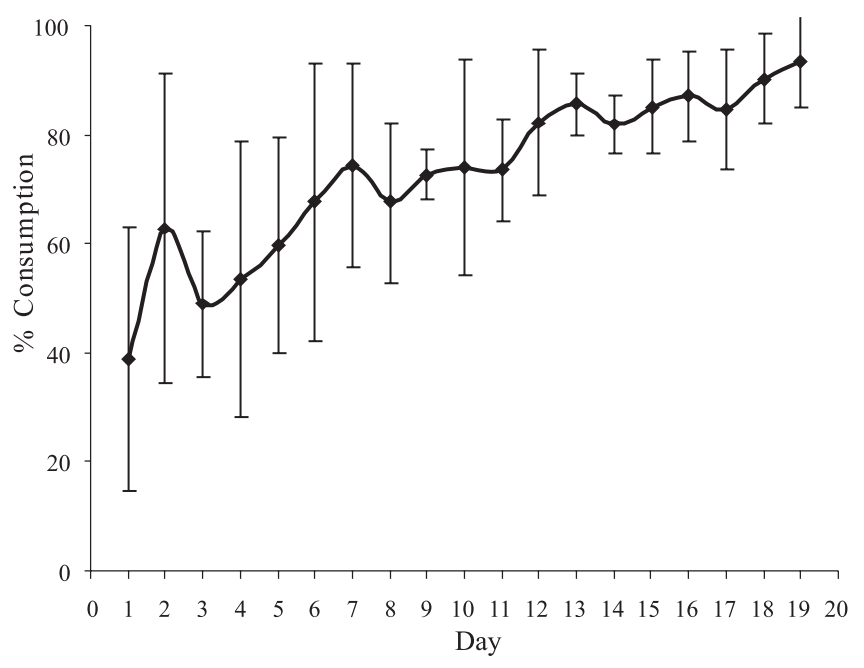

Figure 1 - Adaptation period of foals to Lucerne hay intake. 


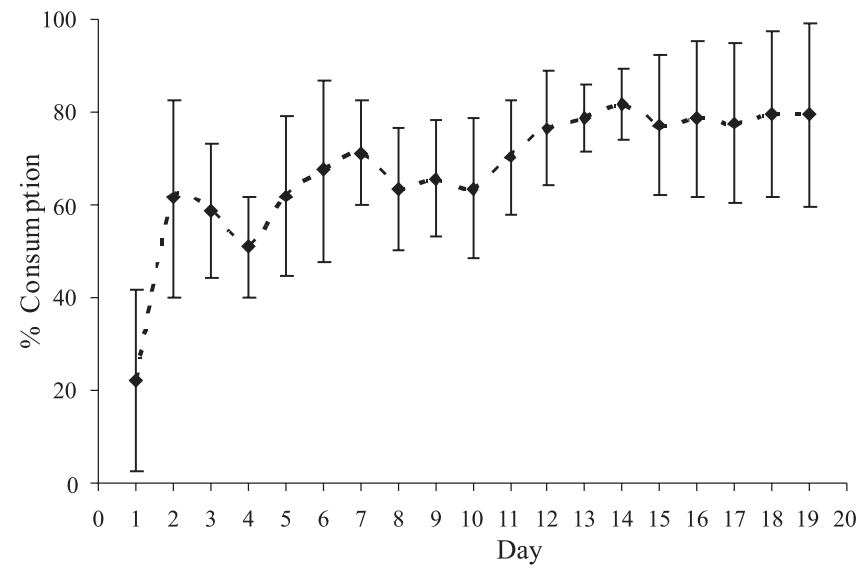

Figure 2 - Adaptation period of foals to Campo Grande stylo hay intake.

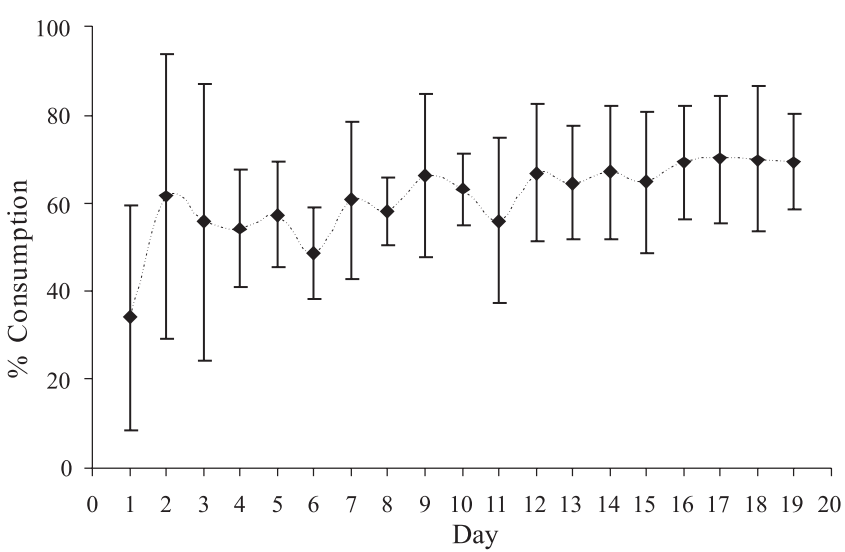

Figure 3 - Adaptation period of foals to Mineirão stylo hay intake.

Horse foals were fed Lucerne hay and two other types of grass (Bermuda and Matua). Matua grass had not been previously tested for voluntary intake. It was observed that voluntary intake was 3.1\% of BW for Lucerne hay, $2.8 \%$ of BW for Matua grass and 2.1\% of BW for Bermuda grass.

Evaluations of alternative roughage intake are scarce in Brazil and evaluations of alternative forage acceptance by foals are nonexistent. However, because of its high nutritional value, Silva et al. (2009), suggested, but did not evaluate the voluntary intake of Mineirão stylo hay in the horse diet.
In this study, it was observed that the foals consumed less Mineirão stylo hay. There are characteristics that are peculiar to the equine species (Domingues, 2009), so information on nutritional quality cannot be applied without careful evaluation of how feed is consumed (Dittrich et al., 2005) or if it is effectively consumed. According to LaCasha et al. (1999), when new feed types are added to the equine diet, voluntary intake should be evaluated.

In this study, foals consumed the same amount of concentrate relative to BW. Therefore, it was concluded that weight gain from concentrate would have been similar for all treatments and differed only because of the type of hay that was voluntarily consumed. So, the coefficient of variation for total intake ( $\mathrm{g} / \mathrm{kg} \mathrm{BW}$ ) was lower in relation to the fixed supply of concentrate, but resulted in a statistically significant difference $(\mathrm{P}<0.05)$ between treatments.

Both hay intake and total intake (g/kg BW) were higher in the diet containing Lucerne hay and lower with Mineirão stylo hay. Campo Grande stylo yielded intermediate intake values.

In their first year of life, foals grow quickly and require adequate nutrition to maintain growth rates equal to their genetic potential (Rezende et al., 2000). Rezende et al. (1986) observed daily weight gains from 0.54 to $0.65 \mathrm{~kg}$ in Mangalarga Marchador foals from weaning to 12 months of age when supplemented with different levels of crude protein (CP) (14, 16 and 18\%). Santos et al. (2005) found similar weight gain results ( $0.77 \mathrm{~kg} /$ day) when Mangalarga Marchador suckling foals were evaluated from birth to 160 days. According to the NRC (2007), weaned foals at six months of age, which have an estimated mature body wheight of $400 \mathrm{~kg}$, gain weight at $0.58 \mathrm{~kg} /$ day. This is similar to the weight gain $(0.58 \pm 0.2 \mathrm{~kg} /$ day $)$ in this study of foals on the diet containing Lucerne hay.

There was no difference $(\mathrm{P}>0.05)$ in weight gain between the diets evaluated. This was unexpected given the intake differences between the types of hay given to the foals. A coefficient of variation of $34.8 \%$ may have negatively affected the comparison. Foals on Campo Grande and Mineirão stylo hay diets had lower daily weight gains, of 0.54 and $0.47 \mathrm{~kg} /$ day, respectively. It is possible that if the trial

Table 2 - Voluntary intake of dry matter from Lucerne hay, Campo Grande and Mineirão stylo hay, total intake and weight gain for Mangalarga Marchador foals

\begin{tabular}{|c|c|c|c|}
\hline Hay & Hay intake (g/kg BW) & Total intake (g/kg BW) & Weight gain (kg/day) \\
\hline Lucerne & $15.6 \pm 1.3 a$ & $27.7 \pm 1.3 \mathrm{a}$ & $0.58 \pm 0.2 \mathrm{a}$ \\
\hline Campo Grande stylo & $14.2 \pm 2.5 \mathrm{ab}$ & $26.3 \pm 2.5 a b$ & $0.54 \pm 0.1 \mathrm{a}$ \\
\hline Mineirão stylo & $11.8 \pm 1.9 b$ & $24.0 \pm 1.9 b$ & $0.47 \pm 0.2 \mathrm{a}$ \\
\hline CV (\%) & 14.0 & 7.6 & 34.8 \\
\hline
\end{tabular}

Means followed by the same letter are not significantly different, SNK test (5\%).

$\mathrm{CV}$ - coefficient of variation. 
period for weight gain had been greater, the difference would have been detected in the variance analysis. It should also be taken into consideration that one of the treatments lost one degree of freedom which may have affected the comparison of averages. So, the final weights of foals receiving Lucerne, Campo Grande and Mineirão hays were 170.6ะ19; $167.8 \pm 11$ and $179.7 \pm 14 \mathrm{~kg}$, respectively.

To supply the nutritional requirements of foals, the diet was balanced according to the NRC (2007) recommendations. When average crude protein ( $\mathrm{kg} /$ day), digestible energy (DE) (Mcal/day) and the CP:DE ratio were calculated for the experimental diets, it was observed that nutritional requirements were met in the diet containing Lucerne hay, but differences in daily CP intake were observed in the diets containing stylo hays (Table 3 ).

Diets containing the stylo hays did not meet the daily protein requirements of these foals at six months of age, and did not differ in this aspect $(\mathrm{P}>0.05)$. Compared with the NRC (2007), deficiencies in protein requirements were 13 and $\mathbf{1 8 . 5 \%}$ for Campo Grande and Mineirão. Energy requirements (Mcal/day), on the other hand, were met by all three diets. The diet containing Lucerne hay met the CP:DE ratio requirements for the foals. However, this ratio was lower than the recommended by the NRC (2007) in the diets containing Campo Grande and Mineirão hays.

One can notice that even though consumption of Campo Grande stylo hay did not differ from that of Lucerne hay, its lower protein content meant that CP requirements were not met and probably, because of this, weight gain was $6.9 \%$ lower than it was for foals consuming the Lucerne hay diet. Protein supplied by Mineirão hay was similar to that of Campo Grande hay $(\mathrm{P}<0.05)$, but resulted in 19\% lower weight gain than animals consuming Lucerne hay. However, one must have in mind that weight gain could have been hampered by the short experimental time frame and/or by the degree of freedom lost in one of the treatments.

Additionally, the timing of forage cutting is very important because hay quality is more associated with the vegetative stage of grass and fertilization than with only the grass species in question (Haddad \& Castro, 1998). In this study, both legumes were cultivated in the same area and cut at same time (137 days); however, at harvest time, Mineirão was still clearly developing, while Campo Grande had already started to flower.

There was no difference $(\mathrm{P}>0.05)$ in average digestibility of diets fed a concentrate to forage ratio of 40:60 (Table 4).

Hintz et al. (1971) worked with a mixed equine diet consisting of concentrate and forage. Even though the diet included various levels of concentrate, the authors found no effect associated with food nutrients.

Similarly, Martin-Rosset \& Dulphy (1987) evaluated the effect of the interaction between forage and concentrate on the digestibility for foals at nine months, fed natural pasture hay supplemented with 0,30 and $60 \%$ concentrate. The authors found no differences in digestibility of organic matter (OM), crude fiber (CF) and starch. Therefore, the proportion of concentrate given to foals did not alter roughage digestibility.

For the diet containing Lucerne hay, the average DM digestibility was $70.3 \%$ (Table 5), which was higher than that described in the literature for a diet consisting exclusively of Lucerne hay.

However, Hintz et al. (1971) fed horses a similar diet consisting of Lucerne hay and concentrate at a ratio of 60:40 and observed digestibility of $69.7 \%$. This value was similar to what was found in the present study and had the same composition and proportion of feeds relative to the Lucerne hay diet.

Most information in the literature refers to diets consisting only of Lucerne hay. For example, Todd et al. (1995) evaluated digestibility in ponies consuming Lucerne hay processed in different forms and observed average dry matter digestibility (DMDC) coefficient values of 61.9\%.

While Crozier et al. (1997) observed average DM digestibility of Lucerne hay at 58\%. LaCasha et al. (1999) evaluated yearling foals on a diet of Lucerne hay and observed values of $63 \%$. Almeida et al. (1999) observed 55.2\% DMDC and Silva et al. (2009), 63.5\%, with mature animals. Crude protein digestibility for the Lucerne hay diet

Table 3 - Dry matter intake of crude protein (CP), digestible energy (DE) and the crude protein:digestible energy ratio (CP:DE) in the diets fed to the foals

\begin{tabular}{lccc}
\hline Diet $($ Concentrate + Hay) & CP intake $(\mathrm{kg} /$ day) & DE intake (Mcal/day) & CP:DE ratio (g/Mcal) \\
\hline Lucerne & $0.65 \pm 0.10 \mathrm{a}$ & $14.0 \pm 2.8$ & $47.2 \pm 2.5$ \\
Campo Grande & $0.47 \pm 0.05 \mathrm{~b}$ & $13.0 \pm 2.0$ & $36.4 \pm 2.1$ \\
Mineirão & $0.44 \pm 0.06 \mathrm{~b}$ & $12.7 \pm 2.5$ & $34.8 \pm 1.7$ \\
NRC $^{1}$ & 0.54 & 12.4 & 43.7 \\
CV (\%) & 14.6 & 18.3 & 5.5 \\
\hline
\end{tabular}

Means followed by the same letter are not significantly different by SNK test (5\%).

${ }^{1}$ Reccomendations for foals, mature body weight $400 \mathrm{~kg}$ (NRC, 2007).

$\mathrm{CV}$ - coefficient of variation. 
Table 4 - Digestibility coefficients of the diets composed of concentrate and of Lucerne hay, Campo Grande and Mineirão stylo hay

\begin{tabular}{lccccccc}
\hline Diet (Concentrate + Hay) & \multicolumn{7}{c}{ Apparent digestibility coefficient (\%) } \\
\cline { 2 - 7 } & DM & OM & CP & NDF & ADF & HEM \\
\hline Lucerne & $70.3 \pm 5$ & $72.2 \pm 4$ & $74.8 \pm 4$ & $57.8 \pm 9$ & $44.7 \pm 10$ & $71.3 \pm 8$ \\
Campo Grande & $69.1 \pm 5$ & $72.0 \pm 4$ & $74.0 \pm 5$ & $57.4 \pm 7$ & $48.3 \pm 8$ & $65.9 \pm 6$ \\
Mineirão & $67.0 \pm 4$ & $69.5 \pm 4$ & $69.9 \pm 5$ & $55.8 \pm 7$ & $42.4 \pm 11$ & $72.0 \pm 3$ & $67.8 \pm 4$ \\
CV (\%) & 6.9 & 5.5 & 6.4 & 13.8 & 21.4 & 11.0 & 6.7 \\
\hline
\end{tabular}

DM - dry matter; OM - organic matter; CP - crude protein; NDF - neutral detergent fiber; ADF - acid detergent fiber; HEM - hemicellulose GE - gross energy; CV - coefficien of variation.

in the present study was $74.8 \%$. In a similar experiment, Hintz et al. (1971) observed crude protein digestibility of Lucerne hay of $75.5 \%$. However, other studies have shown different values when Lucerne hay was offered exclusively. Todd et al. (1995) observed 78.2\%, LaCasha et al. (1999), 83\%, and Silva et al. (2009), 77.4\%. However, Crozier et al. (1997) and Almeida et al. (1999) observed averages of 73\% and $71.2 \%$, which were below those found in the present study. Therefore, in general, the protein digestibility percentages for Lucerne hay were corroborated by results found in the literature. Differences might be associated with hay quality and the methodologies used to estimate digestibility.

Fiber in the Lucerne hay diet yielded digestibility coeficients of 57.8, 44.7 and $71.3 \%$ for neutral detergent fiber (NDF), acid detergent fiber (ADF) and hemicellulose (HEM), respectively. According to Hintz et al. (1971), fiber digestibility, represented by NDF, was $54.8 \%$ for a diet of Lucerne hay and concentrate at a ratio of 60:40, which was similar to the value observed in the present study. Almeida et al. (1999) recorded, for the same forage, NDF, ADF and HEM digestibility at 35.5, 32.9 and 40.2\%, respectively. Crozier et al. (1997) observed fiber fraction digestibility of 47 , 45 and 55\% for the same nutrients, which were closer to the averages found in this experiment.

Trials that fed foals legume stylo hay as the sole source of roughage, with forage to concentrate ratio of 60:40 were not found. However, estimates of the digestibility of Mineirão stylo hay do exist (Silva et al., 2009).

Silva et al. (2009) estimated the digestibility of different forage types in a trial with adult horses using the mobile bag technique. Seven roughage types were evaluated, from which six were legumes. The authors recorded apparent digestibility of DM, OM, CP, NDF, ADF and gross energy (GE) of Mineirão stylo hay at 75.6, 76.4, 94.9, 53.3, 53.5, $75.6 \%$, respectively. In addition, the nutritional composition of Mineirão, cut between 60 and 90 days was described, and had 16.2\% CP, 47.5\% NDF and 33.3\% ADF.

In the present study, legume hay had lower protein content of $11.1 \%$ CP, $67.6 \%$ NDF, $46.6 \%$ ADF and was cut at 137 days, which was later than in the experiment of Silva et al. (2009). This advanced maturity time reduced crude protein and increased fiber levels, thus reducing digestibility. This fact was confirmed since digestibility coefficients in this experiment were lower than those observed by Silva et al. (2009).

No studies on apparent digestibility of Campo Grande stylo hay for horses were found in the literature. So, comparisons with the current study were not possible. However, the similarity in the digestibility of diets containing Lucerne hay and the stylo hays was a good sign, given that these legumes thrive in acid soils with low fertility and have low rainfall requirements (Skerman et al., 1991). In regions with such conditions, legumes are a possibility for inclusion in horse diet. This is especially true for the Campo Grande stylo hay, which had dry matter intake levels equal to that of Lucerne hay. However, further research should be conducted to evaluate animals fed stylo hay as only roughage or combined with other forages.

\section{Conclusions}

Campo Grande stylo hay is consumed at rates similar to Lucerne hay, produces similar weight gain in diets that include concentrate, can be an additional option for feed strategies in horse breeding systems and should be cut before 137 days of vegetative growth. Mineirão stylo hay is not palatable for foals when cut at 137 days of growth.

\section{References}

ALMEIDA, M.I.V.; FERREIRA, W.M.; ALMEIDA, F.Q. et al. Valor nutritivo do capim-elefante (Penninsetum purpureum, Schum), do feno de alfafa (Medicago sativa, L.) e do feno de capim coast-cross (Cynodon dactylon, L.) para equinos. Revista Brasileira de Zootecnia, v.28, n.4, p.743-752, 1999.

ASSOCIATION OF OFFICIAL ANALYTICAL CHEMISTRY AOAC. Official methods of analysis. 16.ed. Arlington: AOAC International, 1995. 1025p.

CROZIER, J.A.; ALLEN, V.G.; JACK, N.E. et al. Digestibility, apparent mineral absorption, and voluntary intake by horses fed Alfafa, Tall fescue, and Caucasian Bluestem. Journal of Animal Science, v.75, p.1651-1658, 1997. 
DitTRICH, J.R.; CARVALHO, P.C.F.; MORAES, A. et al. Preferência de equinos em pastejo: efeito da altura de dosséis de gramíneas do gênero Cynodon. Archives of Veterinary Science, v.10, n.2, p.61-67, 2005.

DOMINGUES, J.L. Uso de volumosos conservados na alimentação de equinos. Revista Brasileira de Zootecnia, v.38, p.259-269, 2009 (supl. especial).

HADDAD, C.M.; CASTRO, F.G.F. Produção de feno. In: SIMPÓSIO SOBRE MANEJO DA PASTAGEM, 15., 1998, Piracicaba. Anais... Piracicaba: FEALQ/ESALQ, 1998. p.151-171.

HINTZ, H.F.; ARGENZIO, R.A.; SCHRYVER, H.F. Digestion coefficients, blood glucose levels and molar percentage of volatile acids in intestinal fluid of ponies fed varying foragegrain ratios. Journal of Animal Science, v.33, p.992-995, 1971.

LaCASHA, P.A.; BRADY, H.A.; ALLEN, V.G. et al. Voluntary intake, digestibility and subsequent selection of matua bromegrass, coastal bermudagrass, and alfafa hays by yearling horses. Journal of Animal Science, v.77, p.2766-2773, 1999.

LIMA, R.A.S.; SHIROTA R.; BARROS, G.S.C. Estudo do complexo do agronegócio cavalo. Piracicaba: ESALQ/USP, 2006. 250p.

MANZANO, A. NOVAES, N.J.; CARVALHO, R.T.L. Substituição do feno de alfafa por feno de Rhodes no desempenho de equinos. Pesquisa Agropecuária Brasileira, v.14, n.3, p.229-235, 1979.

MARTIN-ROSSET, W.; DULPHY, J.P. Digestibility interactions between forages and concentrate in horses: influence of feeding level-comparison with sheep. Livestock Production Science, v.17, p.263-276, 1987.

NUTRIENT REQUIREMENTS COUNCIL - NRC. Nutrient requirements of horses. 6.ed. Washington: National Academy Press, 2007. 341p.
REZENDE, A.S.C.; SAMPAIO, I.B.M.; LAGORRETA, G.L. et al. Efeito de dois diferentes programas nutricionais sobre o desenvolvimento corporal de potros Mangalarga Marchador. Revista Brasileira de Zootecnia, v.29, n.2, p.495-501, 2000.

REZENDE, A.S.C.; VELOSO, J.A.F.; VAL, L.L. et al. Efeito do nível protéico do concentrado suplementar sobre o crescimento de potros da raça Mangalarga Marchador. Arquivo Brasileiro de Medidicina Veterinária e Zootecnia, v.38, n.6, p.927-41, 1986.

SALIBA, E.O.S. Minicurso sobre o uso de indicadores. In: TELECONFERÊNCIA SOBRE INDICADORES EM NUTRIÇÃO ANIMAL, 1., 2005, Belo Horizonte. Anais... Belo Horizonte: Escola de Veterinária/UFMG, 2005. p.23-25.

SANTOS, E.M.; ALMEIDA, F.Q.; VIEIRA, A.A. et al. Lactação em éguas Mangalarga Marchador: Produção e composição do leite e ganho de peso dos potros lactentes. Revista Brasileira de Zootecnia, v.34, n.2, p.627-634, 2005.

SILVA, V.P.; ALMEIDA, F.Q.; MORGADO, E.S. et al. Digestibilidade dos nutrientes de alimentos volumosos determinada pela técnica dos sacos móveis em equinos. Revista Brasileira de Zootecnia, v.38, n.1, p.82-89, 2009.

SKERMAN, P.J.; CAMERON, D.G.; RIVEROS, F. Leguminosas forrajeiras tropicales $\left(n^{\circ} 2\right)$. Roma: FAO, 1991. 707p.

TODD, L.K.; SAUER, W.C.; CHRISTOPHERSON, R.J. et al. The effect of feeding different forms of alfafa on nutrient digestibility and voluntary intake in horses. Journal of Animal Physiology and Animal Nutrition, v.73, p.1-8, 1995.

VAN SOEST, P.J. Nutritional ecology of the ruminant. 2.ed. Cornell University Press, 1994. 476p.

VAN SOEST, P.J.; ROBERTSON, J.P.; LEWIS, B.A. Methods for dietary fiber, neutral detergent fiber, and nonstarch polysaccharides in relation to animal nutrition. Journal of Dairy Science, v.74, p.3583-3597, 1995. 